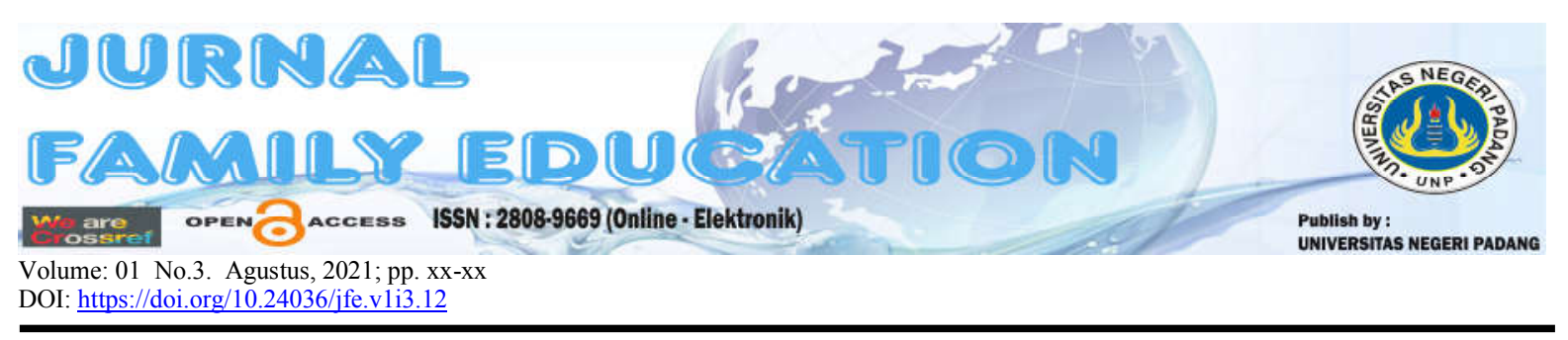

\title{
Implementasi Metode Steam Di Taman Kanak-Kanak
}

\author{
Chintya Maharani, Zulminiati \\ Universitas Negeri Padang \\ * e-mail: Chintyamaharani0411@gmail.com; bundazulminiati@gmail.com
}

\begin{abstract}
STEAM is important in the development of AUD because the STEAM method emphasizes active learning and stimulates children to solve problems. So that here an effort to implement STEAM-Based Learning can be achieved. So that many schools have used the STEAM method, one of which is in Tiara Bunda Kindergarten, here several aspects of development have been developed using this STEAM method, for that the author is interested in exploring and analyzing the process of implementing the STEAM method in Tiara Bunda Kindergarten. The research method used in this research is descriptive qualitative. This research was conducted at Tiara Bunda Pesisir Selatan Kindergarten. Informants or respondents in this study were the Principal and Teachers. Data collection techniques were carried out through observation, interviews and documentation. The data obtained are described in accordance with the existing reality. Data analysis in the form of a description in the form of words and data validity techniques using data validity techniques using data reduction techniques, data presentation, and drawing conclusions. The results of this study indicate that Tiara Bunda Pesisir Selatan Kindergarten has implemented or implemented learning using the STEAM method well. This can be seen from how the learning process takes place and the material provided is in accordance with the form of learning using the STEAM method, be it Science, Technology, Engineering, Arts, and Mathematics has been carried out properly and in accordance with the provisions
\end{abstract}

Keywords: Implementation, STEAM Method, Early Childhood

\section{PENDAHULUAN}

Pendidik pada PAUD mempunyai tugas yang lebih kompleks dari pada pendidik tingkat pendidikan atasnya. Karena itu seorang pendidik PAUD dituntut mampu merancang kegiatan yang menarik dan menantang, melaksanakan pembelajaran menyenangkan, dapat mengamati dan mencatat proses anak. Anak usia dini merupakan individu yang sedang berada pada masa keemasan, dimana pada masa ini anak sedang menjalani suatu proses pertumbuhan dan perkembangan dengan pesat dan fundamental. Anak usia dini merupakan masa peka dalam berbagai aspek perkembangan yaitu masa awal pengebangan kemampuan fisik motorik, bahasa, sosial emosional, serta kognitif. 
STEAM merupakan suatu metode pembelajaran yang merupakan paduan untuk meningkatkan keterampilan berfikir secara ilmiah. Pembelajaran STEAM dapat mendorong anak untuk belajar mengeksplorasi semua kemampuan yang dimilikinya, dengan caranya masingmasing. STEAM dapat menstimulasi keinginan dan motivasi anak mengenai keterampilan berfikir, pemecahan masalah, kerjasama, pembelajaran mandiri, pembelajaran berbasis proyek, pembelajaran berbasis tantangan dan penelitian. Metode STEAM perlu diimplementasikan sejak dini karena paud merupakan salah satu bentuk penyelenggaraan pendidikan yang menitik beratkan pada peletakan dasar, maka dari itulah penting dikenalkan pembelajaran berbasis STEAM sejak dini.

Pada dasarnya, pembelajaran steam yang seharusnya dilakukan dan diterapkan oleh guru melibatkan lima disiplin ilmu (sains, teknologi, teknik, seni, matematika) dan menimbulkan lingkungan belajar yang inklusif di mana semua anak dapat terlibat dan berkontribusi. Metode pembelajaran STEAM menjadi hal yang amat penting dalam perkembangan AUD. Berdasarkan hasil observasi yang peneliti lakukan di TK Tiara Bunda, dalam pembalajaran sekolah tersebut telah menggunakan metode STEAM. STEAM penting dalam perkembangan AUD karena metode STEAM ini lebih menekankan pembelajaran yang aktif dan merangsang anak untuk memecahkan persoalan. Sehingga disini dapat tercapai sebuah upaya Penerapan Pembelajaran Berbasis STEAM. Sehingga telah banyak sekolah yang menggunakan metode STEAM ini salah satunya di TK Tiara Bunda, disini beberapa aspek perkembangan telah dikembangkan dengan menggunakan metode STEAM ini, Menurut (Fadlillah 2012) "Pendidikan anak usia dini adalah pendidikan yang diperuntukkan bagi anak usia 0-6 tahun, yang dimaksudkan sebagai upaya untuk menumbuhkembangkan segala kemampuan (potensi) yang dimiliki sang anak dalam rangka mempersiapkan pendidikan lebih lanjut".

Pentingnya pendidikan usia dini adalah sebagai suatu upaya untuk menumbuh kembangkan, meningkatkan, dan memaksimalkan potensi yang dimiliki oleh anak dalam rangaka mempersiapkan pendidikan lebih lanjut. Salah satu upaya yang dapat diterapkan dalam pendidikan anak usia dini adalah pembelajaran dengan menerapkan metode STEAM. STEAM merupakan muatan pembelajaran yang menggunakan lima ilmu pengetahuan, sains teknologi, teknik, seni dan matematika, secara menyeluruh dan berkaitan satu sama lain sebagai pola pemecahan masalah. STEAM merupakan sebuah pembelajaran yang mendorong anak untuk kreatif dalam pemecahan masalah, berfikir logis, dan dapat berfikir simbolik. STEAM (Science, Technology, Engineering Art and Mathematics) dalam proses pembelajaran dikemas dengan mengkombinasikan sain, teknologi, teknik, matemetika dan seni. Menurut (Agustina and Dkk 2020) menyebutkan "Dalam pembelajaran STEAM diharapkan dapat muncul kemampuan beradaptasi, berfikir luwes, 
berinisiatif, mau mengembangkan diri, produktif, dapat dipercaya, memiliki jiwa kepemimpinan dan tanggung jawab".

Berdasarkan penjelasan tersebut, maka dapat diketahui bahwa upaya penerapan atau implementasi metode STEAM dalam proses pembelajaran diharapkan mampu memunculkan kemampuan beradaptasi, berfikir luwes, berinisiatif, mau mengembangkan diri, produktif, dapat dipercaya, memiliki kepemimpinan dan tanggung jawab. Penerapan pembelajaran dengan menerapkan metode STEAM diharapkan mampu membantu meningkatkan kualitas setiap anak usia dini yang berapa pada tingkat Taman Kanak-kanak.

Taman Kanak-kanak Tiara Bunda Pesisir Selatan, merupakan salah satu Taman Kanakkanak yang dalam pembalajaran sekolah tersebut telah menggunakan metode STEAM. Di sini beberapa aspek perkembangan telah dikembangkan dengan menggunakan metode STEAM ini. Pada dasarnya semua komponen yang terkandung didalamnya harus mampu diterapkan untuk meraih hasil yang maksimal pada anak. Bentuk keberhasilan dalam pengimplementasian metode STEAM dalam pembelajaran adalah guru dapat menerapkan pembelajaran kepada murid, dan mampu dipahami oleh murid secara menyeluruh.

\section{METODE}

Jenis penelitian yang peneliti lakukan adalah kualitatif. Dengan metode penelitian deskriptif. Penelitian kualitatif adalah metode penelitian yang berlandaskan pada filsafat postpositivisme, digunakan untuk meneliti pada kondisi objek yang alamiah, (sebagai lawannya adalah eksperimen) dimana peneliti adalah sebagai insrumen kunci. Sumber data pada penelitian ini adalah informan. Dalam hal ini peneliti mengambil informan penelitian utama adalah semua orang yang berhubungan dengan Taman Kanak-kanak Tiara Bunda. diantaranya kepala yayasan Taman Kanak-kanak Tiara Bunda, kepala sekolah Taman Kanak-kanak Tiara Bunda, guru kelas Taman Kanak-kanak Tiara Bunda dan orang tua dari anak Taman Kanak-kanak Tiara Bunda. Dalam penelitian ini, peneliti menggunakan teknik pengumpulan data yaitu, observasi, wawancara, dan dokumentasi.

\section{Bagaimana cara guru dalam menstimulasi kemampuan sains anak dalam bentuk kegiatan mengamati dan menyelidiki objek serta fenomena alam}

Hasil penelitian yang diperoleh menunjukkan bahwa cara guru dalam menstimulasi kemampuan sains anak dalam bentuk kegiatan mengamati dan menyelidiki objek serta fenomena alam. Hal ini berkaiatan dengan bagaimana proses pembelajaran anak dan proses menstimulasi atau mendorong kemampuan sains anak agar lebih baik dan berkembang dengan cara mengamati dan menyelidiki objek serta fenomena. Hal ini dilakukan guru dengan cara yang dapat dilakukan dalam melakukan stimulasi kemampuan sains anak seperti melakukan percobaan-percobaan yang 
mengarah pada kemampuan sains anak. Seperti percobaan gunung meletus, dan percobaan lainnya.

Hal ini harapkan mampu mendapatkan informasi dan memunculkan gagasan-gagasan baru yang dapat meningkatkan kemampuan sains yang dimiliki. Sehingga kemampuan sains yang dimiliki dapat direspon dan dapat meningkat. Sistem pembelajaran yang diterapkan pada peserta didik secara tidak langsung telah menerapkan sebagian dari metode STEAM.

STEAM merupakan sebuah pembelajaran yang mendorong anak untuk kreatif dalam pemecahan masalah, berfikir logis, dan dapat berfikir simbolik. STEAM (Science, Technology, Engineering Art and Mathematics) dalam proses pembelajaran dikemas dengan mengkombinasikan sain, teknologi, teknik, matemetika dan seni. Menurut (Siantajani and Reswita 2020) bahwa "Sains adalah pengetahuan atau pembelajaran tentang alam berdasarkan fakta-fakta yang dipelajari melalui percobaan dan pengamatan”.

Berdasarkan penjelasan tersebut, maka dapat dipahami bahwa metode STEAM merupakan suatu metode pembelajaran yang mengkedepankan kombinasi antara sains, teknologi, teknik, matemetika dan seni. Dari kutipan di atas, maka jelas terlihat bahwa untuk penerapan salah satu komponen dari STEAM telah diterapkan pada pelaksanaan pembelajaran di TK Tiara Bunda Pesesir Selatan hal ini terlihat dari pembelajaran yang diterapkan mampu dan mengandung kelima unsur dari STEAM tersebut.

\section{Bagaimana guru dalam menstimulasi kemampuan sains anak melalui keterampilan sains dasar, seperti melakukan pengamatan, mengukur dan mengkomunikasikan hasil pengamatan?}

Pada hasil penelitian yang diperoleh, menunjukkan bahwa guru menstimulasikan kepada murid dan yang harus dilakukan oleh murid dengan menggunakan sentra bahan alam dan menyediakan timbangan untuk mengukur suatu berat benda-benda yang ada seperti batu, kayu, dan lain sebagainya. Selanjutnya guru menjelaskan dan selanjutnya menanyakan mengenai perbandingan berat batu dengan sebuah kayu. Seterusnya anak akan berusaha menjelaskan menurut apa yang mereka pahami. Kegiatan pembelajaran seperti ini diharapkan mampu meningkatkan pengetahuan yang dimiliki oleh anak.

Pengetahuan yang dimaksud adalah pengetahuan sains melalui sains dasar seperti melakukan pengamatan, mengukur, dan mengkomunikasikan atau menyampaikan hasil pengamatan yang dilakukan. Dengan cara seperti ini akan pembelajaran ini akan menyediakan stimulus bagi anak dalam upaya mempelajari hal tersebut sehingga mampu mengerti. Menururt (Gunawan 2019) menyebutkan bahwa "Sains adalah kegiatan pemecahan masalah yang dilakukan oleh manusia yang dimotivasikan oleh rasa ingin tahu tentang dunia sekitar mereka dan keinginan 
untuk memahami alam tersebut, serta keingian memanipulasi alam dalam rangka meluaskan keinginan atau kebutuhannya".

Berdasarkan penjelasan tersebut, maka dapat dipahami bahwa pembelajarana sains merupakan kegiatan pemecahan masalah yang dilakukan oelh manusia yang dimotivasikan oleh rasa ingin tahu tentang banyak hal. Ini berarti bahwa pembelajaran sains dasar yang diterapkan oleh pihak sekolah dengan melakukan pengamatan terhadap batu dan kayu dengam melihat massa berat yang dimiliki diharapkan akan menimbulkan rasa ingin tahu dan sekaligus menjadi motivasi bagi anak untuk bisa belajar lebih baik lagi. Selain itu, hasil ini menunjukkan bahwa pembelajaran yang berlangsung pada TK Tiara Bunda pada dasarnya telah menerapkan metode STEAM dalam proses pembelajaran. Hal ini terlihat dari bagaimana konten atau materi yang disampaikan kepada anak-anak yang merupakan bagian dari STEAM. hal ini dapat dilakukan oleh murid dengan menggunakan sentra bahan alam dan menyediakan timbangan untuk mengukur suatu berat bendabenda yang ada seperti batu, kayu, dan lain sebagainya. Selanjutnya guru menjelaskan dan selanjutnya menanyakan mengenai perbandingan berat batu dengan sebuah kayu. Seterusnya anak akan berusaha menjelaskan menurut apa yang mereka pahami. Kegiatan pembelajaran seperti ini diharapkan mampu meningkatkan pengetahuan yang dimiliki oleh anak. Pada pelaksanaan percobaan perbandingan batu dan kayu dengan menggunakan alat timbagan diharapkan mampu meningkat pemahaman anak dalam segi sains, teknologi, teknik, seni, dan matematika.

\section{Bagaimana cara guru dalam menstimulasi kemampuan anak-anak melalui kegiatan penemuan?}

Pada penelitian yang telah dilakukan diperoleh hasil yang menunjukkan bahwa cara guru dalam menstimulasi kemampuan anak-anak melalui kegiatan penemuan yaitu guru dalam menstimulasi atau mendorong kemampuan anak melalui kegiatan penemuan yang diterapkan di sekolah. Dari hasil wawancara yang dilakukan, diketahui bahwa pada pembelajaran yang terjadi guru lebih banyak menggunakan sentra bahan alam, hal ini seperti melihat proses pengembangbiakan kupu-kupu yang dimulai dari ulat menjadi kepompong hingga menjadi seekor kupu-kupu.

Hal ini diharapkan akan munculnya spekulasi anak mengenai proses tersebut. Selain itu, banyak hal yang dapat dilakukan untuk menstimulasi kemampuan anak-anak tersebut. Sehingga diharapkan dengan adanya kegiatan ini mampu meningkatkan rasa ingin tahu anak terhadap penemuan-penemuan lain yang berkaitan dengan ilmu pengetahuan. Pada dasarnya pembelajaran jenis ini juga merupakan bagian dari metode STEAM yang juga pada kenyataannya telah diterapkan oleh pihak guru dari TK Tiara Bunda Pesisir Selatan. Hal ini terlihat dari bagaimana guru memanfaatkan sentra alam untuk menjadi bahan pengamatan anak. Sependapat dengan hal tersebut juga disampaikan oleh (Wahyuningsih and Dkk 2020) menyebutkan "Melalui kegiatan 
STEAM anak dapat mengembangkan potensi dirinya dalam hubungan antara bahan pelajaran dan desain pembelajaran serta lingkungan sekitar anak".

Melihat dari penjelasan tersebut, maka dapat dipahami bahwa pembelajaran atau melalui kegiatan STEAM anak dapat mengembangkan potensi dirinya dalam hubungan antara bahan pelajaran dan desain pembelajaran serta lingkungan sekitar anak. Pada kasus ini secara tidak langsung guru TK Tiara Bunda telah merelisasikan atau mengimplementasikan pembelajaran dengan metode STEAM kepada peserta didik/murid TK Tiara Bunda.

\section{Bagaimana cara guru dalam menstimulasi kemampuan teknologi anak dengan kegiatan seperti mengetik menggunakan otot tangan dan menggambar?}

Pada hasil penelitian yang telah diperoleh mengenai bagaimana cara guru dalam menstimulasi kemampuan teknologi anak dengan kegiatan seperti magnetik menggunakan otot tangan dan menggambar. Dari hasil penelitian tersebut diketahui bahwa guru mengajak anak pada kegiatan sentra bermain peran, dengan mengunakan media telepon. Kemudian meminta anak untuk memainkan peran seolah olah anak lagi menelepon. Disitu berkembang kemampuan otot tangan dengan menekan huruf. Upaya tersebut diharapkan dapat menstimulasi kemampuan anak sehingga mampu meningkatkan kemampuan anak.

Pembelajaran yang diterapkan pada kegiatan belajar mengajar dengan metode seperti ini mampu meningkatkan kemampuan itelegensi anak, juga dapat meningkat kemampuan motorik halus serta kemampuan kognitif sang anak. Hal ini tergambar dari bagaimana proses pembelajaran yang berlangsung seperti yang disebutkan di atas. Kemampuan yang berkaitan dengan teknologi merupakan hal yang penting yang harus diterapkan dan ditanamkan sejak dini dengan memberikan penjelasan mengenai manfaat dan resikonya.

Pada TK Tiara Bunda, terlihat dari hasil penelitian juga menerapakan bagian dari metode STEAM yaitu teknologi. Pembelajaran yang berkaitan dengan teknologi pada awalnya akan diajarkan secara mendasar berkenaan dengan meminta anak untuk memainkan peran seolah olah anak lagi menelepon. Disitu berkembang kemampuan otot tangan dengan menekan huruf. Menurut (Gunawan 2019) "Teknologi secara umum adalah ilmu yang berhubungan dengan alat atau mesin yang diciptakan untuk membantu dan mempermudah manusia dalam menyelesaikan masalah atau pekerjaan yang terdapat di dunia".

Berdasarkan penjelasan dan pendapat di atas, maka dapat dipahami bahwa penerapan pembelajaran dengan metode STEAM dengan menstimulasi kemampuan Teknologi dipergunakan untuk membiasakan anak untuk menggunakan teknologi, sehingga dapat membantu dan mempermudah dalam mengerjakan sesuatu hal. senada dengan hal tersebut juga disampaikan oleh (Wahyuningsih and Dkk 2020) yang menegaskan "Dalam kegiatan pembelajaran metode STEAM 
dipergunakan berbasis teknologi ilmiah dan keampuan untuk memecahkan masalah kehidupan yang mungkin akan dialami anak dalam kehidupan sehari-hari”.

Berlandaskan dengan temuan penelitian, penjelasan dan pendapat di atas, maka pada diketahui mempelajari, mengetahui, dan sebagainya adalah upaya mempermudah manusia untuk menjalani kehidupan, sehingga dapat membatu dikedepannya nanti. Hal yang sama, seperti metode STEAM juga ternyata telah diterapak di TK Tiara Bunda tersebut. Hal ini terbukti dari hasil wawancara bersama informan.

\section{Bagaimana guru dalam menstimulasi kemampuan teknik anak melalui kegiatan menggunakan media untuk merangkai dan menggabungkan sesuatu?}

Pada hasil penelitian yang diperoleh diketahui cara guru dalam menstimulasi kemampuan teknik anak melalui kegiatan menggunakan media untuk merangkai dan menggabungkan sesuatu. Hal ini dilakukan oleh guru dengan cara melakukan upaya menstimulasi kemampuan teknik anak melalui kegiatan merangkai dan mengabungkan. Dilakukan dengan bermain puzzle, dengan bermain puzzle anak akan mendapatkan ide untuk merakit atau merangkai sesuatu, contohnya dengan bermain puzzle tersebut anak bisa membuat rumah, kapal. Selain itu upaya atau kegiatan lain yang dapat dilakukan guru menajak anak bermain lego, dan disini guru meminta anak untuk membuat lego tersebut berbentuk bangunnan, contohnya rumah. Dengan adanya kegiatan ini diharapkan mampu meningkatkan kemampuan anak dalam merangkai dan mengabungkan sesuatu.

Pembelajaran yang diterapkan di atas dengan kegiatan menyusun dan menyatukan/menggabungkan sesuatu menggunakan media lego dan puzzle diharapkan mampu meningkatkan kemampuan anak dalam hal kognitif dan meningkatkan kemampuan teknik dasar, seperti yang diajarkan tersebut. Menurut (Gunawan 2019) “Teknik dalam pendekatan STEAM adalah sebuah keahlian yang dimiliki oleh anak untuk mengoperasikan alat benda atau merangkai sesuatu. Kemampuan teknik anak usia dini meliputi kemampuan merangkai atau membangun suatu bentuk tertentu menggunakan berbagai benda".

Berdasarkan penjelasan tersebut, dapat diketahui bahwa Teknik dalam pendekatan STEAM adalah sebuah keahlian yang dimiliki oleh anak untuk mengoperasikan alat benda atau merangkai sesuatu. Pada pembelajaran di TK Tiara Bunda penerapan metode STEAM dengan mempelajari tentang teknologi adalah bukti bahwa penerapan metode STEAM telah terlaksana/diimplementasikan dengan menggabungkan sesuatu menggunakan media lego dan puzzle diharapkan mampu meningkatkan kemampuan anak dalam hal kognitif dan meningkatkan kemampuan teknik dasar. Sebenarnya pembelajaran ini memiliki banyak manfaat yang sangan berguna bagi kehidupan murid nantinya. Hal ini diperkuat oleh (Muniroh 2019) "Teknik, anak belajar tentang mengoperasikan atau merangkai sesuatu menggunakan berbagai media”. 
Berlandaskan dari penjelasan dan hasil penelitian di atas, yang selanjutnya juga diperkuat oleh pendapat ahli. Maka, dapat diketahui pembelajaran menggunakan sistem STEAM salah satunya dalam bidang teknik memiliki banyak sekali manfaat bagi anak, untuk dimasa saat ini maupun masa mendatang nantinya. Penerapan atau implementasai metode STEAM juga telah dilakukan pada TK Tiara Bunda Pesisir Selatan, hal ini terlihat dari hasil penelitian dan penjelasan di atas.

\section{Bagaimana upaya guru dalam meningkatkan kemampuan seni anak melalui kegiatan seperti melukis, melipat, menggambar dan sebagainya?}

Melihat dari hasil penelitian yang dilakukan maka dapat diketahui bahwa upaya guru dalam meningkatkan kemampuan seni anak melalui kegiatan seperti melukis, melipat, menggambar dan sebagainya dapat dilakukan oleh guru dalam upaya meningkatkan kemampuan seni seorang anak yaitu guru mengajak anak menggambar bebas kemudian guru meminta anak untuk menceritakan hasil dari gambar, selain itu, guru mengajak anak untuk mengenal satu binatang, kemudian meminta anak menggambarnya, bisa juga mengajak anak melipat kertas berbentuk gambar tersebut. namun sebelum itu guru terlebih dahulu guru memperlihatkan dulu gambar yang ingin di kerjakan sama anak, contohnya binatang, disini guru menjelaskan dulu deskripsi binatang tersebut, mengenal bentuknya, barulah meminta anak untuk menggambaranya, atau mewarnai gambar atau belajar melipat kertas membentuk binatang. Langkah ini diharapkan anak mampu meningkatkan kemampuan seni yang dimilikinya. Menurut pendapat (Gunawan 2019) menyebutkan bahwa:

"Kemampuan seni pada anak usia dini meliputi anak mengenal dan menunjukkan berbagai karya aktivitas seni seperti menggambar, melukis dengan kuas, melukis dengan jari, mengecap, melipat, meronce, seni pertunjukan seperti drama, menari dan ekspolasi dengan benda-benda yang dapat digunakan untuk membuat sebuah karya seni”.

Berdasarkan pendapat di atas, maka dapat dipahami bahwa kemampuan seni yang dimiliki oleh anak usia dini meliputi mengenal dan menunjukkan berbagai karya aktivitas seni seperti menggambar, melukis dengan kuas, melukis dengan jari, mengecap, melipat, meronce, dan lain sebagainya. Pada pembelajaran di TK Tiara Bunda Pesisir Selatan Juga pada dasarnya telah menerapkan pembelajaran yang menstimulasi seni kepada muridnya. Pembelajaran tersebut seperti mengajarkan untuk melukis dan mewarnai beranekaragamnya hewan, yang terlebih dahulu dijelaskan. Pembelajaran menerapkan metode STEAM jenis ini (seni) memiliki banyak manfaat positif bagi anak kedepannya.

7. Bagaimana upaya guru dalam menstimulasi kemampuan matematika anak dalam pembelajaran matematika sederhana seperti mengenal ukuran dan warna, bermain memilah bentuk dan mengenal pola? 
Melihat dari hasil penelitian tentang bagaimana upaya guru dalam menstimulasi kemampuan matematika anak dalam pembelajaran matematika sederhana seperti mengenal ukuran dan warna, bermain memilah bentuk dan mengenal pola. Adapun upaya yang dapat dilakukan guru pada saat pembelajaran berlangsung adalah dengan cara lebih banyak dilakukan pada sentra persiapan, dilakukan melalui meronce, dalam meronce terdapat beberapa geomeri, ada tiga bentuk geometri terlebih dahulu diajarkan kepada anak ada itu segitiga, segi empat dan lingkaran, kemudian ukurannya juga, nah dari situ anak bakal dilihat kemahiran anak menyusun rencean tersebut sesuai dengan pola berurut, selain itu juga dapat dilakukan dapat mengajak anak bermain di sentra balok, kemudian mengajak anak untuk membedakan bentuk warna dan pola dari balok tersebut. selain sentra balok hal ini juga dapat dilakukan menggunakan kertas origami dengan cara guru mengajak anak untuk menggunting kertas origami berbagai macam warna, dan meminta anak menggunting berbetuk pola seperti segitiga, lingkaran, segi empat. Kemudian guru memberitahu warna apa dan pola apa yang telah digunting anak. Guru mengkomunikasikan kembali. Hal ini diharapkan anak mampu memiliki kemampuan matematika anak dalam pembelajaran matematika sederhana seperti mengenal ukuran dan warna, bermain memilah bentuk dan mengenal pola sehingga mampu membantu mempersiapkan diri dan pengetahuan untuk memamsuki jenjang pendidikan yang lebih tinggi. Menurut (Gunawan 2019) menjelaskan:

"Matematika pada anak usia dini adalah kegiatan belajar tentang konsep matematika melalui aktifitas bermain dalam kehidupan sehari-hari dan bersifat ilmiah. Permainan pada matematika yang dapat dimainkan antara lain bermain ukuran dan warna, permainan memilah bentuk, permainan mengenal pola. Pembelajaran matematika bagi anak perlu dikaitkan dengan hal yang nyata, dan terkait langsung dengan aktivitas manusia".

Berdasarkan penjelasan di atas, dapat dipahami bahwa penerapan metode STEAM dengan menstimulasikan kemampuan matematika anak dapat dilakukan melalui aktivitas bermain seharihari dan bersifat ilmiah. Permainan yang dimaksud adalah permainan ukuran dan warna, memilah bentuk, dan masih banyak lainnya yang bertujuan untuk meningkatkan kemampuan matematika anak. Hal yang serupa juga diterapkan oleh TK Tiara Bunda Pesisir Selatan. Hal ini memiliki manfaat yang sangat besar bagi setiap anak. Menurut (Muniroh 2019) "Matematika, anak dapat mengetahui bermain ukuran dan warna, permainan memilah bentuk, permainan mengenal pola”.

Berdasarkan penjelasan tersebut, dapat dipahami bahwa dengan mempelajari dan menstimulasikan kemampuan matematika anak, akan membantu untuk mengetahui bermain ukuran dan warna, permainan memilah bentuk, dan permainan mengenal pola. Sehingga dengan banyaknya manfaat yang diperoleh akan membantu anak untuk menambah wawasan dan pengetahuan mengenai matematika sederhana yang diperoleh dari penerapan metode STEAM di TK Tiara Bunda. 
Chintya Maharani, Zulminiati

\section{KESIMPULAN}

Berdasarkan dari hasil penelitian dilakukan dan yang selanjutnya dilakukan analisis serta pembahasan terhadap temuan penelitian mengenai penerapan atau implementasi metode STEAM di TK Tiara Bunda. Dari hasil penelitian dan pembahasan secara keseluruhan dapat dikatakan bahwa di TK Tiara Bunda Pesisir Selatan telah menerapkan/mengimplementasikan pembelajaran menggunakan metode STEAM dengan baik. Hal ini terlihat dari bagaimana proses pembelajaran yang berlangsung dan materi yang diberikan sesuai dengan bentuk pembelajaran menggunakan metode STEAM.

Secara keseluruhan materi pelajaran serta praktik yang dilakukan pada saat mengajar, mengandung metode STEAM didalamnya, baik itu sains, teknologi, teknik, seni, dan matematika. Hal ini diharapkan mampu meningkatkan kemampuan anak dalam keseluruhan bidang tersebut. Sehingga anak mampu mempersiapkan diri untuk menghadapi dan menjalani jenjang pendidikan yang lebih tinggi.

\section{DAFTAR PUSTAKA}

Agustina, D., and Dkk. 2020. "Pembelajaran STEAM Pada Pembuatan Instalasi Penjernihan Air Menggunakan Botol Plastik Air Mineral Untuk Mengembangkan Kreativitas Anak Usia Dini." CERIA (Cerdas, Energik, Responsif, Inovatif, Adaptif) 3(4): 323-28.

Fadlillah, Muhammad. 2012. Desain Pembelajaran Paud. Yogyakarta: Ar-Ruzz Media.

Gunawan, Pria. 2019. Pembelajaran STEAM (Science, Technology, Engineering, Art, Mathematics) Dengan Pendekatan Saintifik. Makassar.

Muniroh, Munawar. 2019. "Implementation Of STEAM (Science Technology Engineering Art Mathematics)." Jurnal Ceria 2(5).

Siantajani, W., and R. Reswita. 2020. "Pengembangan Model Pembelajaran Sains Teknologi, Art, Engineering and Mathematics Pada Kurikulum PAUD.” Jurnal Golden Age 4(2): 297-309.

Wahyuningsih, Siti, and Dkk. 2020. "The Utilizaion Of Loose Parts Media In STEAM Learning for Early Chilhood.” Early Chilhood Education and Development Journal 2(2): 1-5. 